\title{
Study of relations among age at first calving, average weight gains and weights from weaning to maturity in Nellore cattle
}

\author{
Arione Augusti Boligon', Lucia Galvão de Albuquerque ${ }^{2,3,4}$, Maria Eugênia Zerlotti \\ Mercadante ${ }^{4,5}$, Raysildo Barbosa Lôbo 6
}

\author{
1 Pós-graduação em Genética e Melhoramento Animal, FCAV/UNESP - Jaboticabal, SP. Bolsista FAPESP. \\ 2 Departamento de Zootecnia, FCAV/UNESP - Jaboticabal, SP. \\ ${ }^{3}$ Bolsista de produtividade do CNPq. \\ 4 Pesquisador do INCT-CA. \\ ${ }^{5}$ Estação Experimental de Zootecnia de Sertãozinho - IZ/APTA/SAA-SP - Caixa Postal 63 - 1CEP: 4160-000 - Sertãozinho, SP. \\ ${ }^{6}$ ANCP-Ribeirão Preto, SP.
}

ABSTRACT - Data from 23,120 Nellore animals were used to estimate genetic parameters for age at first calving, average gains from weaning to yearling and from yearling to after yearling, weaning weight, yearling weight, after yearling weight and weight at 2 and 5 years of age. Animal models were fitted by Restricted Maximum likelihood Method. Estimate heritability for age at first calving, weaning to yearling weight gain, yearling to after yearling weight gain, weight at weaning, yearling weight, after yearling weight and weight from 2 to 5 years of age were $0.17 \pm 0.01 ; 0.23 \pm 0.03 ; 0.25 \pm 0.03 ; 0.28 \pm 0.02$; $0.26 \pm 0.03 ; 0.30 \pm 0.03 ; 0.32 \pm 0.02$ and $0.36 \pm 0.04$, respectively. The genetic correlation estimates between age at first calving and weight traits ranged from -0.26 to -0.14 . The genetic correlation estimates between age at first calving and average gains were also negative, but higher $(-0.29$ and -0.32$)$. In general, these results indicate that selection for average gains will promote changes in age at first calving and female mature weight. Improvement in reproductive performance could be obtained with the inclusion of the age at first calving in the selection index.

Key Words: beef cattle, genetic parameters, heritability, productive and reproductive traits

\section{Estudo das relações entre a idade ao primeiro parto, ganhos em peso e pesos da desmama à maturidade em bovinos da raça Nelore}

RESUMO - Dados de 23.120 animais da raça Nelore foram utilizados para estimar herdabilidade e correlações genéticas para a idade ao primeiro parto, o ganho em peso da desmama ao ano e do ano ao sobreano, o peso à desmama, o peso ao ano, o peso ao sobreano e os pesos aos 2 e aos 5 anos de idade. Utilizou-se o método da máxima verossimilhança restrita, em análise multicaracterística. As herdabilidades estimadas para idade ao primeiro parto, ganho da desmama ao ano, ganho do ano ao sobreano, peso à desmama, peso ao ano, peso ao sobreano e peso aos 2 aos 5 anos foram de $0,17 \pm 0,01 ; 0,23 \pm 0,03$; $0,25 \pm 0,03 ; 0,28 \pm 0,02 ; 0,26 \pm 0,03 ; 0,30 \pm 0,03 ; 0,32 \pm 0,02$ e $0,36 \pm 0,04$, respectivamente. Correlações genéticas baixas e negativas foram estimadas entre a idade ao primeiro parto e os pesos medidos em diferentes idades, que variaram de $-0,26$ a $-0,14$. As correlações genéticas estimadas entre a idade ao primeiro parto e os ganhos de peso também foram negativas, porém levemente superiores $(-0,29$ e $-0,32)$. Os resultados indicam que a seleção para maior ganho de peso pode reduzir a idade ao primeiro parto e aumentar o peso adulto de fêmeas da raça Nelore. Mudança genética mais rápida para diminuição da idade ao primeiro parto das fêmeas pode ser obtida com a inclusão dessa característica nos índices de seleção.

Palavras-chave: bovinos de corte, características produtivas e reprodutivas, herdabilidade, parâmetros genéticos

\section{Introduction}

Individual animal data or expected progeny differences for weights and weight gain obtained in the early ages are incorporated in the beef cattle selection index. These traits are indicative of the animal growth potential and allow the selection of animals that show higher growth precocity and higher slaughter weight.
However, the selection only for higher weight at young ages can increase the mature weight due to genetic correlations from medium to high magnitudes between weights in different ages (Silva et al. 2000; Boligon et al. 2009). Similarly, the average weight gain obtained in different growth stages are also, either to a low or high level, genetically correlated to mature body weight. But, females with higher mature weight may have their reproductive

Received October 10, 2008 and accepted March 25, 2009.

Corresponding author: arioneboligon@yahoo.com.br 
performance reduced because, according to some studies, there are unfavorable genetic correlations between mature weight and reproductive traits (Winkler et al., 1993; Meyer et al., 2004).

Age at first calving is the most used female reproductive trait to evaluate the fertility in beef cattle. This trait can be measured early and it is easily obtained, being expressed in most of the females placed in breeding. Nevertheless, the direct selection for younger age at first calving is not simple because the reproductive traits generally have low heritability.

Some authors have reported estimates of negative genetic correlations, from low to medium magnitude, and in such cases a favorable direction between the age at first calving and weights from weaning (Mercadante et al., 2000; Talhari et al., 2003; Pereira et al., 2005; Boligon et al., 2008a), which ranged from -0.67 to -0.09 (age at first calving $\times$ weaning weight), -0.32 to -0.07 (age at first calving $x$ yearling weight), -0.41 to -0.29 (age at first calving $\times$ after yearling weight) and -0.31 (age at first calving $\times$ weight at first calving), for Zebu cattle. According to Talhari et al. (2003), before investing in a selection program for higher weight, it is necessary to know the relationship between weights obtained at different ages and reproductive efficiency traits, in view of the economic importance of these traits in livestock cattle.

This study was conducted to estimate genetic parameters and correlations between age at first calving, average gains from weaning to yearling and yearling to after yearling with weights obtained from weaning to maturity in Nellore cattle.

\section{Material and Methods}

Data were collected from 23,120 Nellore animals, born between 1975 and 2002, belonging to 8 farms participating in the Programa de Melhoramento Genético da Raça Nellore (Nellore Cattle Breeding Program). The animals were weighed every 90 days from birth to 18 months of age, and those that remained in the herds as breeding stock continued to be weighed every 90 days. The births occurred throughout the year, but were more frequent in Spring and Summer. Animals were weaned, on average, at 240 days of age. Only data of animals, which were products of artificial insemination, reared on pasture without supplemental feed and weaned by their biological mothers were considered.

The following traits were studied: age at first calving; average gains from weaning to yearling and yearling to after yearling, weaning weight, yearling weight, weight after yearling, weight at 2 and 5 years of age. The weights were defined as: weaning weight - weight taken closest to 240 days of age (ranging from 180 to 300 days of age); yearling weight - weight taken closest to 365 days of age (ranging from 305 to 425 days of age); weight after yearling - weight taken closest to 550 days of age (ranging from 490 to 610 days of age); weight at 2 and 5 years of age - weights taken closest to 2 years (ranging from 650 to 810 days of age) and 5 years (ranging from 4.5 to 5.5 years of age). Animals whose measures were higher or lower than the mean of their contemporary groups (plus or minus 3 standard deviations) for either trait were discarded.

Four birth seasons were defined: from December to February (season 1), from March to May (season 2), from June to August (season 3), and from September to November (season 4). Two breeding seasons were defined: from April to June (season 1) and from October to December (season 2). The contemporary group was defined by including animals born on the same farm, year and season of birth, and sex. For age at first calving, the breeding season was also included in the contemporary group. It was not included the sex for contemporary group for age at first calving and weight at 5 years of age because only information of females was considered. Contemporary groups with less than 4 animals were excluded (Table 1).

The (co)variance components and the genetic parameters were obtained by using the restricted maximum likelihood method, in multiple-trait animal models, with the WOMBAT program (Meyer, 2006). For all traits, direct and residual genetic additive were considered as random effects. For weaning weight, it was also included the maternal

Table 1 - Observation number, means and standard deviation for the traits

\begin{tabular}{lccc}
\hline Trait & Number of observations & Mean & Standard deviation \\
\hline Age at first calving (days) & 1,938 & $1,050.00$ & 109.07 \\
Average gains from weaning to yearling $(\mathrm{kg})$ & 10,329 & 41.04 & 22.12 \\
Average gains from yearling to after yearling $(\mathrm{kg})$ & 12,642 & 76.32 & 24.65 \\
Weaning weight $(\mathrm{kg})$ & 11,125 & 196.72 & 27.23 \\
Yearling weight $(\mathrm{kg})$ & 17,136 & 233.05 & 42.50 \\
Weight after yearling $(\mathrm{kg})$ & 14,242 & 317.49 & 17.49 \\
Weight at 2 years of age $(\mathrm{kg})$ & 5,378 & 364.25 & 59.70 \\
Weight at 5 years of age $(\mathrm{kg})$ & 1,222 & 514.24 & 59.25 \\
\hline
\end{tabular}


genetic and maternal permanent environmental as random effects. Contemporary group was included in the model as a fixed effect. Linear and quadratic effects of the animal age at recording (except for average gains from weaning to yearling and yearling to after yearling), and dam age at calving were included as covariables. For average gains from weaning to yearling and yearling to after yearling it was also considered numbers of days from weaning to yearling and from yearling to after yearling, respectively, as covariable. A pedigree file containing the identification of the animal, sire and dam was used, with the relationship matrix comprising a total of 26.924 animals.

The matrix representation of the general model is:

$$
y=X \beta+Z_{a} a+Z_{m} m+Z_{p} p+e
$$

where: $y$ is the vector of observations; $b$, vector of fixed effects; $a$, vector of direct additive genetic effects; $m$, vector of maternal additive genetic effects; $p$, vector of maternal permanent environmental effects; and $e$, vector of residual random errors associated with the observations. $X, Z_{a}, Z_{m}$ and $Z_{p}$ are the incidence matrices related to $b, a$, $m$ and $p$ to $y$. It is assumed that $\mathrm{E}[y]=X \beta, \operatorname{Var}(a)=A \otimes \Sigma_{a}$, $\operatorname{Var}(m)=A \otimes \Sigma_{m}, \operatorname{Var}(p)=I_{\mathrm{Nm}} \otimes p$ e $\operatorname{Var}(e)=I_{\mathrm{N}} \otimes \mathrm{e}$, where $\Sigma_{a}$ is the matrix of direct additive genetic (co)variances between traits; $\Sigma_{m}$ is the maternal additive genetic covariance matrix; $\Sigma_{p}$, maternal permanent environmental covariance matrix; $\Sigma_{e}$, residual covariance matrix; $A$, relationship matrix; $I$, identity matrix, $\mathrm{N}_{\mathrm{m}}$, number of dam of animals with records, $\mathrm{N}$, number of animals with records and $\otimes$, the direct product between matrices. It is assumed that $m$ and $p$ are not correlated.

\section{Results and Discussion}

The heritability estimate for age at first calving (Table 2) was close to those described in the literature for Zebu cattle, with values ranging from 0.13 to 0.18 (Silva et al., 2000;
Talhari et al., 2003; Boligon et al., 2008a,b). For Nellore females, Mercadante et al. (2000) obtained higher heritabilities $(0.26$ and 0.27$)$. In this study, the heritability estimates for age at first calving $(0.17 \pm 0.01)$ indicate small additive genetic variability in the expression of this trait, suggesting that the direct selection for age at first calving should be small annual genetic gain.

The large influence of non-additive genetic effects and environmental factors on age at first calving indicates that the expression of this trait depends on adequate management conditions. However, the traditional management adopted in Brazilian farms, where the heifers are exposed to reproduction by considering the body weight and/or female age, can affect the early identification of sexual precocity heifers reducing the genetic variability of the trait. However, even though improvements in the management of animals can be quick alternatives to reduce its expression, given the economic importance of reproductive traits, the genetic selection at long-term could have a positive impact on the herd productivity.

When studying different models in terms of fixed effects that affect the age at first calving in Nellore females, Boligon et al. (2008b) reported that different data set and models cause small changes on genetic parameters for this trait. However, the age that the females are exposed to reproduction can change the genetic variability of the age at first calving, being always greater when the females are exposed to breeding season at an earlier age, around 12-18 months of age (Pereira et al., 2002; Dias et al., 2004). The variation in the estimates related in the literature review also reflects the genetic diversity found in the different regions of Brazil, since differences in allele frequencies result in changes in additive genetic variance and, consequently, heritability.

The direct heritability estimates for average gains from weaning to yearling and yearling to after yearling found in

Table 2 - (Co)variance components estimates and genetic parameters for age of first calving and growth traits by multiple-trait analysis

\begin{tabular}{|c|c|c|c|c|c|c|c|c|}
\hline Estimates & $\begin{array}{c}\text { Age at } \\
\text { first calving }\end{array}$ & $\begin{array}{l}\text { Average gains } \\
\text { from weaning } \\
\text { to yearling }\end{array}$ & $\begin{array}{l}\text { Average gains } \\
\text { from yearling } \\
\text { to after yearling }\end{array}$ & $\begin{array}{l}\text { Weaning } \\
\text { weight }\end{array}$ & $\begin{array}{l}\text { Yearling } \\
\text { weight }\end{array}$ & $\begin{array}{l}\text { Weight after } \\
\text { yearling }\end{array}$ & $\begin{array}{l}\text { Weight at } 2 \\
\text { years of age }\end{array}$ & $\begin{array}{l}\text { Weight at } 5 \\
\text { years of age }\end{array}$ \\
\hline$\sigma_{\mathrm{a}}^{2}$ & 1225.02 & 86.08 & 189.14 & 110.71 & 207.74 & 315.08 & 402.39 & 487.04 \\
\hline$\sigma_{\mathrm{m}}^{2}$ & - & - & - & 42.38 & - & - & - & - \\
\hline$\sigma_{p}^{2}$ & - & - & - & 52.42 & - & - & - & - \\
\hline$\sigma_{\mathrm{e}}^{\mathrm{P}}$ & 6746.87 & 288.18 & 567.42 & 189.88 & 582.14 & 735.19 & 855.08 & 865.85 \\
\hline $\mathrm{h}^{2}{ }_{\mathrm{a}}$ & $0.17(0.01)$ & $0.23(0.03)$ & $0.25(0.03)$ & $0.28(0.02)$ & $0.26(0.03)$ & $0.30(0.03)$ & $0.32(0.02)$ & $0.36(0.04)$ \\
\hline $\mathrm{h}_{\mathrm{m}}^{2}$ & - & - & - & $0.10(0.01)$ & - & - & - & - \\
\hline $\mathrm{p}^{2}$ & - & - & - & 0.11 & - & - & - & - \\
\hline
\end{tabular}

$\sigma^{2}{ }_{\mathrm{a}}$ (direct additive genetic variance); $\sigma_{\mathrm{m}}^{2}$ (maternal additive genetic variance); $\sigma_{\mathrm{p}}^{2}$ (variance due to maternal permanent environmental effects); $\sigma_{\mathrm{e}}^{2}$ (environmental variance); $\mathrm{h}^{2}$ a (heritability of direct effects and standard error); $\mathrm{h}^{2}{ }_{\mathrm{m}}$ (heritability of maternal effects and standard error) and $\mathrm{p}^{2}$ (maternal permanent environmental as proportions of phenotypic variances). 
this study were higher than the estimate of 0.16 and 0.21 , respectively, reported in Nellore cattle by Paneto et al. (2002). However, for Nellore cattle, Holanda et al. (2004) obtained direct heritabilities for weight gain between 120 and 300 days of age equal to those described in the present study (0.23) and lower value for weight gain between 300 and 600 days of age (0.06). In general, the heritability estimates for weight gain in different ages were in moderate magnitude, indicating that the use of these traits as a selection criterion can increase the weight gain for the corresponding period.

The heritability estimates for weaning to maturity weights were close to those reported by Mercadante et al. (2000), Pereira et al. (2005) and Boligon et al. (2008a), in Nellore and Tabapuã cattle. For the weights starting from 2 years of age, the heritability estimates were superior regarding to the weights obtained in young ages. Those results suggest that a considerable portion of the variation for these traits is due to the differences in the animal genetic merit, suggesting that the weaning to mature weights should respond to the individual selection.

The maternal heritability estimate for weaning weight was similar to that described in the literature, i.e., 0.10 to 0.17 (Mercadante et al., 2000; Bertazzo et al., 2004; Boligon et al., 2008a). The maternal ability is shown in the pre-natal stage because of placental differences until the post-natal stage due to care and milk production levels. This influence is evidenced mainly until weaning, because the calf depends almost exclusively on the dam. In the present study, this influence in weaning weight was responsible for $23.98 \%$ of the total phenotypic variation.

The estimates of genetic correlations between age at first calving and weaning to after yearling weights were negative, ranging from low to moderate in magnitude (Table 3). These results are close to those described by Talhari et al. (2003) and Boligon et al. (2008a), who reported negative genetic correlations between age at first calving and weights in different ages, i.e., -0.12 and -0.18 (age at first calving and weaning weight); -0.32 and -0.25 (age at first calving and yearling weight) and -0.19 and -0.34 (age at first calving and weight after yearling), respectively. On the other hand, Silva et al. (2000) estimated a higher genetic correlation (-0.58) between the age at first calving of females and yearling weight and Pereira et al. (2005) estimated genetic correlation of -0.07 among these same traits.

By using age at first calving obtained in Nellore females exposed to reproduction at 14 and 26 months of age, Pereira et al. (2001) showed a low and positive genetic correlation between the age at first calving and weaning weight $(0.10)$, and a negative one with the weight after yearling, -0.01 (age at first calving of females exposed at 14 months of age $\times$ weight after yearling) and -0.15 (age at first calving of females exposed at 26 months of age $\times$ weight after yearling). According to these authors, the results indicate that selection for larger weaning weight would negatively affect the sexual precocity of the herd.

Genetic associations obtained between age at first calving and young weights indicate that the selection for weight would not harm the reproductive precocity of animals, but the low magnitude of these estimates suggests that a small number of genes are contributing to the phenotypic expression of both traits. However, these genetic correlations should be carefully interpreted, because the selection criterion adopted by the farms, which favors the heaviest and precocious animals, can decrease the phenotypic variability of these traits. In addition, the heifers that failed (no pregnancy) were not considered in the analyses. In relation to precocity mating, Marson et al. (2006) showed that the inclusion of the heifer weight as covariable in the model for heifer pregnancy probability at 14 months of age decreased the heritability from 0.41 to 0.18 , suggesting that the heifers body weight is very important for the beginning of the reproductive life and part of the genetic variation of this trait can be due to body weight genetic variation.

Table 3 - Estimates of genetic correlations between age at first calving and productive traits in Nellore cattle obtained by multiple-trait analysis

\begin{tabular}{|c|c|c|c|c|c|c|c|c|}
\hline & $\begin{array}{c}\text { Age at } \\
\text { first calving }\end{array}$ & $\begin{array}{l}\text { Average gains } \\
\text { from weaning } \\
\text { to yearling }\end{array}$ & $\begin{array}{l}\text { Average gains } \\
\text { from yearling } \\
\text { to after yearling }\end{array}$ & $\begin{array}{c}\text { Weaning } \\
\text { weight }\end{array}$ & $\begin{array}{c}\text { Yearling } \\
\text { weight }\end{array}$ & $\begin{array}{c}\text { Weight after } \\
\text { yearling }\end{array}$ & $\begin{array}{l}\text { Weight at } 2 \\
\text { years of age }\end{array}$ & $\begin{array}{l}\text { Weight at } 5 \\
\text { years of age }\end{array}$ \\
\hline $\begin{array}{l}\text { Age at first } \\
\text { calving }\end{array}$ & 1.00 & -0.29 & -0.32 & -0.20 & -0.24 & -0.26 & -0.20 & -0.14 \\
\hline $\begin{array}{l}\text { Average gains } \\
\text { from weaning } \\
\text { to yearling }\end{array}$ & - & 1.00 & 0.52 & 0.47 & 0.51 & 0.42 & 0.39 & 0.30 \\
\hline $\begin{array}{l}\text { Average gains } \\
\text { from yearling } \\
\text { to after yearling }\end{array}$ & g & - & 1.00 & 0.41 & 0.54 & 0.57 & 0.43 & 0.32 \\
\hline
\end{tabular}


Genetic correlation between age at first calving with weight at 2 and 5 years of age showed low magnitudes, indicating favorable few associations among these traits (Table 3). In general, our results suggest that genetic selection based on weight, mainly from the weaning to after yearling period, should result in reduction of the age at first calving. However, at long-term, this selection may be increasing mature weight of the cow as shown by Silva et al. (2000) and Boligon et al. (2009). Thus, the inclusion of age at first calving in the selection index becomes an interesting alternative, since this trait has few genetic associations with mature weight.

The genetic associations between age at first calving and weight gain were also negative but of greater magnitude, favorable to the selection (Table 3). In Nellore cattle, similar results were obtained by Boligon et al. (2008a) who observed that females with greater potential for after weaning growth were more precocious at first calving. Selection for greater weight gain should result in higher reproductive precocity (lower age at first calving), but with increases in mature females weight. Thus, in herds where the aim is to reduce the age at the first calving maintaining constant the mature weight the cow, the use of weight gains as the sole selection criteria is not recommended.

In Nellore cattle, Pereira et al. (2001) showed negative genetic associations between age at first calving of females exposed at 14 and 26 months of age and weight gain at 345 days of age (-0.08 and -0.03 , respectively), indicating that females with higher growth rates will reach the puberty earlier and, therefore, the first calving will be earlier. However, according to these authors, the low correlation suggests that there is a threshold of weight gain below which the females have harmed reproduction. Thus, there would be differences especially between females that grow very slowly and those with fast growth. Upon reaching the minimum value of weight gain that does not harm the beginning of the puberty, all animals would have similar performance.

The genetic correlations between weight gain and weight at early ages were close to 0.50 indicating that the selection for higher weights, such as weaning and yearling weight, can improve growth rate of animals.

In general, animals with greater weight gains tend to present higher mature weight, indicating the selection regarded to weaning to yearling weight gain or yearling to after yearling weight gain could lead to an increase in the size of the mature animals, which is not always desired. In this study, the genetic correlation between average gains from weaning to yearling and from yearling to after yearling was high and positive (0.52), indicating that most of the genes responsible for expression of these traits are the same. Thus, animals with more weight gain from weaning to yearling tend to gain more weight in subsequent ages.

The sexual precocity evaluated by age at first calving seems to be associated with higher rates of body growth in young Nellore animals, showing the importance of growth selection. However, these genetic correlations are moderate, suggesting lower response in the reduction of age at first calving when considering only weight gain in breeding programs. Thus, the inclusion of age at first calving in the selection index can improve more quickly the precocity of the females.

\section{Conclusions}

The inclusion of age at first calving in the selection index should improve the reproductive performance of females. Furthermore, the trait shows little genetic association to mature weight and can be used in herds that need to keep the female mature weight constant. In the studied herds, the disposal of young cows regarded to weights and/or weight gain may reduce at long-term the age at first calving of females. However, the selection considering only a greater weight gain until after yearling can cause increased female mature weight that depending on the production system, is not desirable.

\section{References}

BERTAZZO, R.P.; FREITAS, R.T.F.; GONÇALVES, T.M. et al. Parâmetros genéticos de longevidade e produtividade de fêmeas da raça Nelore. Revista Brasileira de Zootecnia, v.33, n.5, p.1118-1127, 2004.

BOLigon, A.A.; AlBUQUERQUE, L.G.; RORATO, P.R.N. Associações genéticas entre pesos e características reprodutivas em rebanhos da raça Nelore. Revista Brasileira de Zootecnia, v.37, n.4, p.596-601, 2008a.

BOLIGON, A.A.; VOZZI, P.A.; NOMELINI, J. et al. Parâmetros genéticos para idade ao primeiro parto estimados por diferentes modelos para rebanhos da raça Nelore. Ciência Rural, v.38, n.2, p.432-436, 2008b.

BOLIGON, A.A.; ALBUQUERQUE, L.G.; MERCADANTE, M.E.Z. et al. Herdabilidades e correlações entre pesos do nascimento à idade adulta em rebanhos da raça Nelore. Revista Brasileira de Zootecnia, v.38, n.12, p.2320-2326, 2009.

DIAS, L.T.; EL FARO, L.; ALBUQUERQUE, L.G. Efeito da idade de exposição de novilhas à reprodução sobre estimativas de herdabilidade da idade ao primeiro parto em bovinos Nelore. Arquivo Brasileiro de Medicina Veterinária e Zootecnia, v.56, p.370-373, 2004.

HOLANDA, M.C.R.; BARBOSA, S.B.P.; RIBEIRO, A.C. et al. Tendências genéticas para crescimento em bovinos Nelore em Pernambuco, Brasil. Archivos de Zootecnia, v.53, p.185-194. 2004.

MARSON, E.P.; FERRAZ, J.B.F.; BALIEIRO, J.C.C. et al. Estimates of variance components and heritability for heifers pregnancy probability in Bos taurus x Bos indicus composite heifers with RFLP markers information. In: WORLD CONGRESS ON 
GENETIC APPLIED TO LIVESTOCK PRODUCTION, 8., 2006, Belo Horizonte. Proceedings... Belo Horizonte, 2006 (CD-ROM). MERCADANTE, M.E.Z.; LÔBO, R.B.; OLIVEIRA, H.N. Estimativas de (co)variância entre características de reprodução e de crescimento em fêmeas de um rebanho Nelore. Revista Brasileira de Zootecnia, v.29, n.4, p.997-1004, 2000.

MEYER, K.; JOHNSTON, D.; GRASER, H. Estimates of the complete genetic covariance matrix for traits in multi-trait genetic evaluation of Australian Hereford cattle. Australian Journal of Agricultural Research, v.55, p.195-210, 2004.

MEYER, K. "WOMBAT" - Digging deep for quantitative genetic analyses by restricted maximum likelihood. In: WORLD CONGRESS ON GENETIC APPLIED TO LIVESTOCK PRODUCTION, 8., 2006, Belo Horizonte. Proceedings... Belo Horizonte, 2006. (CD-ROM).

PANETO, J.C.C.; LEMOS, D.C.; BEZERRA, L.A.F. et al. Estudo de características quantitativas de crescimento dos 120 aos 550 dias de idade em gado Nelore. Revista Brasileira de Zootecnia, v.31, n.2, p.668-674, 2002.

PEREIRA, E.; ELER, J.P.; FERRAZ, J.B.S. Análise genética de algumas características reprodutivas e suas relações com o desempenho ponderal na raça Nelore. Arquivo Brasileiro de Medicina Veterinária e Zootecnia, v.53, p.720-727, 2001.
PEREIRA, E.; ELER, J.P.; FERRAZ, J.B.S. Análise genética de características reprodutivas na raça Nelore. Pesquisa Agropecuária Brasileira, v.37, p.703-708, 2002.

PEREIRA, J.C.C.; RIBEIRO, S.H.A.; SILVA, M.A. et al. Análise genética de características ponderais e reprodutivas de fêmeas bovinas Tabapuã. Arquivo Brasileiro de Medicina Veterinária e Zootecnia, v.57, p.231-236, 2005.

SILVA, A.M.; ALENCAR, M.M.; FREITAS, A.R. et al. Herdabilidades e correlações genéticas para peso e perímetro escrotal de machos e características reprodutivas e de crescimento de fêmeas, na raça Canchim. Revista Brasileira de Zootecnia, v.29, n.6, p.2223-2230, 2000.

TALHARI, F.M.; ALENCAR, M.M.; MASCIOLI, A.S. Correlações genéticas entre características produtivas de fêmeas em um rebanho da raça Canchim. Revista Brasileira de Zootecnia, v.32, n.4, p.880-886, 2003.

WINKLER, R.; PENNA, V.M.; PEREIRA, C.S. et al. Estudo das relações entre o tamanho corporal e algumas características reprodutivas em fêmeas bovinas adultas da raça Guzerá. In: REUNIÃO ANUAL DA SOCIEDADE BRASILEIRA DE ZOOTECNIA, 30., 1993, Rio de Janeiro. Anais... Rio de Janeiro: Sociedade Brasileira de Zootecnia, 1993. p.292. 